\title{
The Characteristics of Impaired Physical Mobility Nursing Diagnosis Among Patients with Stroke
}

\author{
I Gede Purnawinadi ${ }^{\mathrm{a}}$ \\ ${ }^{a}$ Faculty of Nursing of Universitas Klabat
}

\begin{abstract}
A valid nursing diagnosis is very important in nursing care. Clinical indicators are required to validate nursing diagnoses to reduce the risk of misdiagnosis. The accuracy of clinical indicators is determined by the limitation of characteristics and related factors. The purpose of this study was to describe the characteristics nursing diagnosis of impaired physical mobility. This research was a descriptive study conducted by direct assessment through observation in clinical practice. There were 20 records of stroke patient documentation used in this study, with total sampling as the sampling technique. The results showed that the limitations of the main characteristics that emerged in stroke patients were dyspnea after activity (90\%), gait disorder (100\%), slow motion (100\%), spastic movements (100\%), uncoordinated movements (100\%), posture instability (100\%), difficulty flipping position (100\%), limited range of motion (100\%), discomfort (100\%), decreased fine motoric skills (90\%), decreased gross motoric skills (100\%), and moving tremor (90\%). Nurses are expected to focus on main characteristics that arise during the assessment of stroke patients with nursing diagnoses of impaired physical mobility in order to plan effective nursing actions. For further investigators it is recommended to use valid instruments in conducting the assessment so that these characteristics can be a more accurate indicator in nursing diagnosis.
\end{abstract}

Keywords: Characteristics, impaired, physical mobility, stroke

\section{Introduction}

The functional abnormalities of central nervous system that occur when the blood supply to the brain is disrupted known as cerebrovascular disorders (Pandit, Matthews, \& Sangle, 2017). Disorders due to cerebrovascular disease are complications of various disorders affecting the central nervous system (Chow, Marra, \& Cho, 2011). Stroke occurs due to the interruption of blood supply to the brain tissue, due to rupture of blood vessels or blockage by clots that inhibit oxygen supply and nutrients, resulting in damage to brain tissue. The most common symptoms of stroke are sudden weakness or numbness in the face, arms or legs, most often on one side of the body. Other symptoms include: difficulty walking, dizziness, loss of balance or coordination; severe headache without known cause; unconscious or not be aware. The effect of a stroke depends on which part of the brain is injured and how much the severity can cause sudden death (WHO, 2014).

World Heart Federation (2016) stated that cerebrovascular disorders are the primary neurological problem in the world. Stroke is the third cause of death with overall mortality of $18 \%$ to $37 \%$. Globally, stroke is the second leading cause of death at the age of over 60 years, and the fifth cause of death at the age of 15 to 59 years. Every year, 15 million people worldwide suffer a stroke, nearly six million people die and another five million suffer permanent disability after dementia. Stroke is the fifth leading cause of death in the United States and is a major cause of serious disability for adults. About 795,000 people in the United States have a stroke every year and every 40 seconds, someone in the U.S. has a stroke (Centers for Disease Control and Prevention, 2018). 
The Republic of Indonesia's Ministry of Health's Health Research and Development Agency through the results of Basic Health Research (Riskesdas) in 2013 showed the prevalence of stroke in Indonesia based on a diagnosis of health personnel by 7 per mile and based on a diagnosis of health workers who showed symptoms of 12.1 per mile. The increase in the prevalence of stroke is seen in the increase in the age of respondents. The increase in stroke prevalence based on interviews increased from 8.3 per 1000 in 2007 to 12.1 per 1000 in 2013. Stroke prevalence was based on the highest diagnosis of health workers in North Sulawesi (10.8 \%o), followed by DI Yogyakarta (10.3\%o), Bangka Belitung and DKI Jakarta 9.7 per mile respectively.

The results of research conducted by Amiman, Tumboimbela, and Kembuan (2016) by collecting secondary data based on medical records of stroke patients hospitalized with a diagnosis of stroke at Prof. Dr. R. D. Kandou Manado in July 2015-June 2016 period was 293 patients, the number of stroke cases was high because RSUP was a referral hospital in North Sulawesi. Unhealthy lifestyles in North Sulawesi society tend to be dominated by cultural and indigenous conditions inherent in the individual itself, for example, the Minahasa ethnic community has a party habit followed by a meal party or eating foods that are mostly derived from animal fats, thus increasing risk of stroke with the condition of cerebral tissue hypoperfusion. (Meilani, Kandou, Ottay, Kaunang, 2014).

Hypoperfusion that persists longer than can be tolerated by brain tissue can trigger cell death. Blood brain barrier collapses cause fluid influx into brain tissue resulting in cerebral edema. Patients with extensive infarction are accompanied by cerebral edema, clinical signs of lifethreatening intra-cranial hypertension such as headache, vomiting and impaired consciousness, so the role of nurses is needed as service providers and educators who are able to provide nursing care to clients with strokes through the nursing process approach the right one (Murti, 2014).

A valid nursing diagnosis can help resolve a patient's problem, but the process of identifying an appropriate nursing diagnosis is very difficult because the human response is complex and unique. In addition, a valid nursing diagnosis is very important to reduce the risk of diagnosing errors (Herdman \& Kamitsuru, 2015). The main problem in stroke patients is that they are susceptible to a decrease in circulation of brain tissue, causing damage to brain cells that can interfere with neuoromuscular function, so that the physical accessibility barrier becomes an important nursing diagnosis to note.

Limitation of nursing diagnoses characteristics of physical mobility in stroke patients based on NANDA 10th edition, 20152017 definition and classification are dyspnea after activities, walking disorders, slow movements, spastic movements, uncoordinated movements, posture instability, difficulty turning positions, limited range of motion, discomfort, decreased fine and rough motor skills, and tremors due to movement (Herdman \& Kamitsuru, 2015).

Errors in establishing nursing diagnoses lead to errors in determining goals and interventions that have an impact on not overcoming the patient's problems, increasing the period of care and the cost of care and the risk of complications (Summers, Leonard, \& Wenworth, 2009). Therefore, when establishing a nursing diagnosis must focus on the accuracy of clinical indicators (Souse et al., 2013). Based on the background discussed, the purpose of this study was to identify the limitations of the characteristics of physical mobility barriers of stroke patients in IRINA F Neuro RSUP. Prof. DR. R.D. Kandou Manado.

\section{Methodology}

This study was a descriptive study with retrospective approach, conducted by documentation study on nursing assessment report through observation in clinical practice. Literature review was done to define the limitations of characteristics theoretically and be the evidence based in the implementation of clinical practice.

\section{Population and Sample}

The subjects of this study were 20 stroke patients who were admitted in the Neuro RSUP Inpatient Installation of Prof. DR. R.D. Kandou Manado during the period of 5 to 15 November 2017 with total sampling as the sampling technique. The inclusion 
criteria of the study subjects were patients with a medical diagnosis of ischemic or haemorrhagic stroke.

\section{Measures and Instrument}

The instrument in this study was a checklist of the limitations of characteristics from the nursing diagnosis of ineffective cerebral tissue perfusion made by the researcher based on NANDA-edition 10, definition and classification of 2015-2017 (Herdman \& Kamitsuru, 2015) and adjustment of indicators adopted from a nursing diagnostic book with NIC intervention and NOC result criteria (Wilkinson, 2007). The checklist sheet consisted of twelve indicators limitations characteristics of impaired physical mobility. All data were collected at the participants by interview and assessed through direct observation.

\section{Statistical Analysis}

The data analysis was done as univariate, which was by looking at the characteristics of each of the variables studied, and thus it only produced the distribution and percentage on the limitations of characteristics variable and was presented in tabular form. Data is processed using a computer program, such as Microsoft Excel and Statistical Package for the Social Sciences (SPSS).

\section{Results and Discussion}

The results in this study describe the distribution of research subjects based on age, gender, type of stroke, and the description of the limitations of nursing diagnoses characteristics of physical mobility that occur in stroke patients.

\section{Results}

Characteristics of Patients by Age

Data analysis of the characteristics of patients from observations made by the researcher based on demographic data age.
Table 1. Characteristics of Patients by Age

\begin{tabular}{ccccc}
\hline Variabel & Mean & Min- & Max- & SD \\
\hline Age & 51,15 & 37 & 80 & 11,627 \\
\hline
\end{tabular}

Based on table 1, it shows that the average age of the 20 stroke patients was 51.15 years old. The youngest patient was 37 years old and the oldest was 80 years old, with a standard deviation of 11,627 .

Characteristics of Patients by Sex

Data analysis of the characteristics of patients from observations made by the researcher based on demographic data Sex.

Table 2. Characteristics of Patients by Sex

\begin{tabular}{lcc}
\hline Sex & Frequency & $\%$ \\
\hline Male & 14 & 70 \\
Female & 6 & 30 \\
Total & 20 & 100 \\
\hline
\end{tabular}

Based on table 2, we can see that from 20 stroke patients, most of them were male with a total of 14 patients $(70 \%)$, and female were only 6 patients $(30 \%)$.

Characteristics of Patients by Types of Stroke Data analysis of the characteristics of patients from observations made by the researcher based on demographic data types of stroke.

Table 3. Characteristics of Patients by Types of Stroke

\begin{tabular}{lcc}
\hline Type of Stroke & Frequency & $\%$ \\
\hline Haemorrhagic & 9 & 45 \\
Non Haemorrhagic & 11 & 55 \\
Total & 20 & 100 \\
\hline
\end{tabular}

Table 3 shows that of 20 stroke patients, most had non-haemorrhagic stroke with a total of 11 patients $(55 \%)$ and haemorrhagic stroke with a total of 9 patients $(45 \%)$. 
Characteristics of Nursing Diagnosis of Ineffective Cerebral Tissue Perfusion in Stroke Patients

The results of data analysis from observations and assessments that have been conducted based on theoretical review showed that there were 12 limitations of characteristic that appeared in stroke patients. The complete limitations of characteristics of the research results can be seen in table 4 .

Table 4. Characteristics of Impaired Physical Mobility

\begin{tabular}{lccc}
\hline Limitations of Characteristics & $\mathrm{n}$ & $\mathrm{f}$ & $\%$ \\
\hline Dyspnea after activity & 20 & 18 & 90 \\
Gait disorder & 20 & 20 & 100 \\
Slow motion & 20 & 20 & 100 \\
Spastic movements & 20 & 20 & 100 \\
Uncoordinated movements & 20 & 20 & 100 \\
Posture instability & 20 & 20 & 100 \\
Difficulty flipping position & 20 & 20 & 100 \\
Limited range of motion & 20 & 20 & 100 \\
Discomfort & 20 & 20 & 100 \\
Decreased fine motoric skills & 20 & 18 & 90 \\
Decrease gross motoric skills & 20 & 20 & 100 \\
Moving tremor & 20 & 18 & 90 \\
\hline
\end{tabular}

Based on Table 4. it can be seen that there are 9 main characteristics in the diagnosis of physical mobility disorders that occur in 20 stroke patients (100\%), including walking disorders, slow motion, spastic movements, uncoordinated movements, posture instability, difficulty turning positions, limited range of motion, discomfort, and decreased gross motor skills, while dyspnea after activity, decreased fine motor skills, and tremor due to movement of 18 patients $(90 \%)$ in subjects the study.

\section{Discussion}

Age is one of the characteristics that is irreversible, in epidemiological studies is an important variable because there are quite a lot of diseases which are found with a variety of frequency caused by age (Noor, 2008). Research conducted by Sofyan, Sihombing, and Hamra (2015) showed that there is a significant relationship between age and stroke.
Stroke is a neurologic disease that occurs due to the disruption of blood supply to a part of the brain. The incidence of stroke increases with age; the older of individual, the higher the chance of having stroke (Wayunah and Saefulloh, 2017). Increase of age is associated with aging process, where all the organs experience a decline in function including the brain blood vessels becoming inelastic, especially the endothelial thickening, causing the lumen of blood vessels to become narrow and impacts on the decrease of cerebral blood flow (Wiyadi, Parellangi, and Prawita, 2017).

Stroke events were observed more frequently in men than in women. However, as women's life expectancy is higher than that of men, it is not impossible that in other studies about stroke women have higher rates than men (Nastiti, 2012). Sex is a biological division that occurs in each body that has physiological differences which are hormonal. Although physically male is stronger than female, but women have stronger immune system (Sudarma, 2008).

The results of this study are in line with a study conducted by Laily (2017), wherein the results showed that of 88 respondents, male sex experienced ischemic stroke $(75 \%)$, greater than female. Statistical analysis performed showed a significant relationship between sex and ischemic stroke occurrence with chances of male respondents 4,765 times more at risk of ischemic stroke compared to women.

Stroke is a neurological disorder or brain tissue perfusion disorder caused by the destruction of blood vessels that can kill brain cells (cerebral infarction); the death of these tissues can lead to loss of function controlled by the tissue (Farida \& Amalia, 2009). Rosjidi \& Nurhidayat (2014) defined stroke as a perfusion disorder of brain tissue caused by occlusion (blockage), embolism and bleeding (pathology in the brain itself is not because of external factors) that result in permanent or temporary disorder.

The results of this study are in line with the research conducted by Raharjo (2015), in which out of 126 stroke patients, it 
was found that most of the stroke experienced by patients was non haemorrhagic stroke (87.3\%). Similarly, a study conducted by Nastiti (2012) found that of 152 stroke patients, the proportion of ischemic stroke $(85 \%)$ was higher than that of haemorrhagic stroke (15\%). Incidence of stroke in developing countries such as Asia, showed that ischemic stroke is at $70 \%$, while haemorrhagic stroke is only $30 \%$ (Iskandar, 2004). Based on this data, it can be seen that the occurrence of ischemic strike has a greater proportion compared to haemorrhagic stroke.

Based on Table 4. it can be seen that there are 9 main characteristics in the diagnosis of physical mobility disorders that occur in 20 stroke patients $(100 \%)$, namely walking disorders, slow motion, spastic movements, uncoordinated movements, posture instability, difficulty turning positions, limited range of motion, discomfort, and decreased gross motor skills.

The movement and posture are governed by the nervous system which can be achieved through the regulation of muscle contraction and the secretion of the active chemicals by the gland, so that all of these activities are the motor functioning of the nervous system (Guyton \& Hall, 2011). Impaired perfusion of brain tissue can damage the motor neuronal pathways, resulting in stroke patients experiencing motor dysfunction or weakness in the extremities (Brunner \& Suddarth, 2002). This motor dysfunction causes stroke patients to experience a decline in mobility function.

Stroke causes inhibition in the central nervous system component in nerve impulse delivery mechanism manifested by decreased functional abilities, both fine motor and gross motor skills that constitute a person's basic ability to perform daily activities (Cahyati, 2011).

Limitations in some or all ranges of motion independently of stroke patients are also caused by patient limitations in mobilization. The range of motion is the maximum number of movements that the joint may perform in one of three body pieces: sagittal, frontal and transversal. Sagittal pieces are lines that pass through the body from front to back, dividing the body into the left and right. Frontal pieces pass through the body from side to side and divide the body into the front and back. Transverse pieces are horizontal lines that divide the body into the top and bottom. The role of nurses in stroke patients with decreased functional ability is to improve optimal mobility, comfort, and ability by creating a supportive environment by compensating for functional changes (Potter \& Perry, 2006).

\section{Conclusions and Recommendations}

The average age of 20 stroke patients in this study was 51.15 years with the youngest age being 37 years and the oldest age was 80 years. Most are male (70\%) and experience nonhemorrhagic stroke (55\%). Limitations of the main characteristics in the diagnosis of physical mobility disorders that appeared in 20 stroke patients $(100 \%)$ were walking disorders, slow motion, spastic movements, uncoordinated movements, posture instability, difficulty reversing positions, limited range of motion, discomfort, and decline rough motoric skills, while dyspnea after activity, decreased fine motor skills, and tremor due to moving 18 patients (90\%) in subject of the study.

Nurses are expected to be able to recognize and focus on the main characteristics that arise when conducting a study on stroke patients, then other characteristics are used to complement the characteristic limitations found in patients as accurate clinical indicators to perform nursing diagnoses of physical mobility disorders so that the risk of diagnosing errors can be reduced, and planning effective nursing actions can be done well. For further researchers it is recommended to use valid instruments to measure the characteristics of nursing diagnoses, so that these characteristics can be more accurate indicator of nursing diagnosis. 


\section{References}

Ackley, B.J., Ladwig, G.B. (2014). Nursing Diagnosis Handbook: An EvidanceBased Guide to Planning Care. Tenth Edition. Maryland Heights, Missouri: Mosby Elsevier.

Amiman, R.C., Tumboimbela, M.J., Kembuan, M.A. (2016). Gambaran Length of Stay Pada Pasien Stroke Rawat Inap Di RSUP. Prof. D.R. R.D. Kandou Manado Periode Juli-Juli 2016. Jurnal E-Clinic Vol. 4, No. 2. 2016. Retrieved from https://ejournal.unsrat.ac.id/index.php/e clinic/article/view/14500/14073.

Anonim. (2018). Asuhan Keperawatan Pasien Stroke. Nutra Jaya Prima. Retrieved from

http://www.obatjantungstroke.com/askep -strokel.

Badan Penelitian dan Pengembangan Kesehatan (BALITBANGKES)

Kementerian RI. (2013). Riset Kesehatan Dasar. Retrieved from http://www.depkes.go.id/resources/down load/general/Hasil\%20Riskesdas\%2020 13.pdf.

Baehr, M. (2010). Diagnosis Topik Neurologi DUUS, Jakarta : EGC.

Brunner \& Suddarth. (2002). Buku Ajar Keperawatan Medikal Bedah edisi 8, volume 3. Jakarta: Penerbit Buku Kedokteran EGC.

Cahyati, Y. (2011). Perbandingan Latihan ROM Unilateral dan Latihan ROM Bilateral Terhadap Kekuatan Otot Pasien Hemiparese Akibat Stroke Iskemik di RSUD Kota Tasikmalaya dan RSUD Kab. CIamis. Depok: Universitas
Indonesia. $\quad$ Retrieved from http://lontar.ui.ac.id/file?file $=$ digital/20 282727-T\%20Yanti\%20Cahyati.pdf.

Centers for Disease Control and Prevention. (2018). Stroke. 1600 Clifton Road Atlanta, GA USA. Retrieved from https://www.cdc.gov/stroke/index.htm.

Chow, F.C., Marra, C.M., \& Cho, T.A. (2011). Cerebrovascuar Disease in Central Nervous System Infection. US National Library of Medicine, National Institute of Health: PubMed.gov. Retrieved from https://www.ncbi.nlm.nih.gov/pubmed/21 964846.

Coupland, A.P., Thapar, A., Qureshi, M.I., Jenkins, H., \& Davies, A.H. (2017). The Definition of Stroke. Journal of The Royal Society of Medicine. Vol. 110 (1) 9-12. Retrieved from journals.sagepub.com/doi/pdf/10.1177/0 141076816680121.

Farida, I., Amalia, N. (2009). Mengantisipasi Stroke. Yogyakarta: Bukubiru.

Guyton \& Hall. (2011). Buku Ajar Fisiologi Kedokteran edisi 11. Penerbit Buku Kedokteran EGC.

Herdman, T.H., Kamitsuru, S. (2015). Diagnosis Keperawatan: Definisi dan Klasifikasi 2015-2017. Edisi 10. (Nursing Diagnoses: Definition and Classification). Jakarta: Penerbit Buku Kedokteran EGC.

Iskandar, J. (2004). Panduan Praktis Pencegahan dan Pengobatan Stroke. Jakarta: PT Bhuana Ilmu Populer.

Laily, S.R. (2017). Hubungan Karakteristik Penderita dan Hipertensi dengan 
Kejadian Stroke Iskemik. Jurnal Berkala Epidemiologi, Vol.5, No.1, January 2017: 48-59. Retrieved from https://media.neliti.com/media/publicati ons/75921-ID-none.pdf.

Loebis, B., Liza, R.G. (2015). Gangguan Psikotik Akibat Stroke Iskemik. Jurnal Kesehatan Andalas, Vol.4, No.2. Retrieved from http://download.portalgaruda.org/articl e.php? article $=359517 \&$ val $=7288 \&$ title =Gangguan $\% 20$ Psikotik\%20Akibat\%20 Stroke\%20Iskemik.

Meilani, J., Kandou, G.D., Otttay, R.I. dan Kaunang, W.P.J. (2014). Gambaran Kebiasaan Makan Makanan Beresiko Penyakit Jantung Koroner Pada Etnis Minahasa Di Kecamatan Tomohon Utara Kelurahan Kakaskasen 1. Jurnal Kedokteran Komunitas dan Tropik. Vol.2, No.2, May 2014. Retrieved from https://ejournal.unsrat.ac.id/index.php/J KKT/article/.../5328/4841.

Murti, A. S. (2014). Asuhan Keperawatan Pada Tn. M Dengan Gangguan Sistem Persarafan: stroke non hemoragik di ruang anggrek rumah sakit umum daerah pandan arang boyolali. Naskah Publikasi, Fakultas Kesehatan UMS. Retrieved from http://eprints.ums.ac.id/31103/12/NASK AH_PUBLIKASI.pdf.

Muttaqin, A. (2010). Pengantar Asuhan Keperawatan Klien Dengan Gangguan Sistem Persarafan. Jakarta: Salemba Medika.

Nastiti, D. (2012). Gambaran Faktor Risiko Kejadian Stroke Pada Pasien rawat Inap di Rumah Sakit Krakatau Medika. Depok: Skripsi FKM UI. Retrieved from http://lib.ui.ac.id/file?file=digital/20289 574-S-Dian\%20Nastiti.pdf.

Noor. N.N. (2008). Epidemiologi Edisi Revisi. Jakarta: Penerbit Rineka Citra.

Pandian, J.D. \& Sudhan, P. (2013). Stroke Epidemiology and Stroke Care Services in India. J Stroke. Sep 2013; 15(3): 128134. Retrieved from http://www.ncbi.nlm.nih.gov/pmc/articl es/PMC3859004/.

Pandit, R.B., Matthews, M., \& Sangle, S. (2017). Assessment of Neurological Deficit among Cerebrovascular Accident Patient in Selected Hospital. International Journal of Health Science \& Research. Vol.7; Issue:2. Retrieved from http://www.ijhsr.org/IJHSR_Vol.7_Issue. 2_Feb2017/36.pdf.

Raharjo, A.S. (2015). Hubungan Faktor Risiko usia, Jenis Kelamin, dan Pekerjaan dengan Jenis Stroke di Poli saraf RSUP Kraton kabupaten Pekalongan. Pekalongan: STIKES Muhamadiyah Pekajangan. Retrieved from http://www.e-skripsi.stikesmuhpkj.ac.id/eskripsi/index.php? $p=$ fstream\& fid $=1092 \&$ bid $=1154$.

Sofyan, A.M., Sihombing, I.Y., hamra, Y. (2015). Hubungan Umur, Jenis Kelamin, dan Hipertensi dengan Kejadian Stroke. Kendari: $\quad$ Fakultas Kedokteran Universitas Halu Oleo (UHO). Retrieved from http://ojs.uho.ac.id/index.php/medula/art icle/download/182/125.

Souse, V., Lopes, M., Araujo, T. Rolim, I.L.,Oliveira,T.F. (2013). Clinical Indicators of Ineffective Airway Clearance for Patients in the Cardiac 
Postoperative Period. European Journal of Cardiovascular Nursing 2013; 12(2):193-200. Retrieved from https://www.ncbi.nlm.nih.gov/pubmed/22 531662.

Sudarma, M. (2008). Sosiologi Untuk Kesehatan. Jakarta: salemba Medika.

Summers, D., Leonard, A., Wentworth, D. (2009). Comprehensive Overview of Nursing and Interdisciplinary Care of The Acute Ischemic Stroke Patient. A Scientific Statement From The American Heart Association 2009; 40:2911-2944. Retrieved from https://www.ncbi.nlm.nih.gov/pubmed/19 478222.

Wayunah, Saefulloh, M. (2017). Analisis Faktor Yang Berhubungan Dengan Kejadian Stroke Di RSUD Indramayu. Indramayu: STIKES. Retrieved from http://ejournal.upi.edu/index.php/JPKI/a rticle/download/4741/3300.

Wilkinson, J.M. (2007). Buku Saku Diagnosa Keperawatan Dengan Intervensi NIC dan Kriteria Hasil NOC. Jakarta: Penerbit BUku Kedokteran EGC.

Wiyadi, Parellangi, Prawita, W.H. (2017). Faktor-Faktor Yang Berhubungan Dengan Kejadian Penyakit Stroke. Mahakam Nursing Journal Vol.2, No.2, Nov 2017:80-87. Retrieved from http://ejournalperawat.poltekkeskaltim.ac.id/ojs/index.php/nursing/articl e/download/101/30/.

World Health Organization. (2014). Global Status Report on Noncommunicable Diseases : Stroke, Cerebrovascular Accident. Departement of NCDs, Disability, Violence and Injury Prevention. Retrieved from http://www.who.int/topics/cerebrovascul ar_accident/en/.

World Heart Federation. (2016). Stroke. Geneva, Switzerland, Retrieved from http://www.world-

heartfederation.org/cardiovascularhealt $h /$ strokel.

Yani, F.I.A. (2010). Perbedaan Skor Kualitas Hidup Terkait Kesehatan Antara Pasien Stroke Iskemik serangan Pertama dan Berulang. Surakarta: Skripsi Fakultas Kedokteran, Universitas Sebelas Maret. Retrieved from https://eprints.uns.ac.id/8354/1/1321006 08201011321.pdf. 